\title{
COMMUNITY BASED FAMILY SUPPORT SERVICES FOR FAMILIES AT-RISK: SERVICES RENDERED BY CHILD AND FAMILY WELFARE ORGANISATIONS
}

\section{Marianne Strydom}

\section{INTRODUCTION}

In accordance with South African policy documents and legislation (Department of Social Development, 2004; Children's Act 38 of 2005, Section 2(a)White Paper for Social Welfare, 1997) social work service delivery to families where child abuse and neglect occur, must be focused mainly on family preservation through rendering preventative and early intervention services thereby preventing statutory services. Preventative services are, as directed by the ISDM (Department of Social Development, 2006), the primary level of service delivery, by linking families to resources which can limit risky behaviour and to implement a developmental welfare policy. Strong focus is placed on the development of resources in communities to support families and to build capacity, before family crises could develop (Department of Social Development, 2006). Within this context the purpose of this article is to investigate the support (prevention) services available to at-risk families at family welfare organisations to prevent the removal of children and to enhance family preservation.

\section{FAMILY PRESERVATION AND FAMILY SUPPORT SERVICES}

Family preservation services are aimed at keeping children safe in their families through intervention, and at increasing the family's coping skills by strengthening family bonds as well as facilitating the family's utilisation of formal and informal resources (Al, Stams, Bek, Damen, Asscher \& Van der Laan, 2012; Ryan \& Shuerman, 2004, Tracy, 1995). In SA policy documents (Department of Social Development, 2004) family preservation is described as a strategy to empower families to allow children optimal development and to prevent them from being removed from the care of their families.

Theoretically family preservation services include different types of services, namely family support services (community work services), family centred services and intensive crisis services (counselling and concrete services). Family support services which include resources, as well as supportive and educational services must be available to all parents in the community (Pecora, Fraser, Nelson, McCroskey \& Meezan, 1995; Tracy, 1995). Examples of family support services are parent education programmes, community-based support services such as play groups, feeding schemes, day care facilities and community-based network interventions, such as home visiting programmes and school or community-based resource centres (Armstrong \& Hill, 2001; Katz, La Placa \& Hunter, 2007; Lord, Southcott \& Sharp, 2011; Tracy, 1995).

Family support services essentially entail the provision of services as mentioned above by means of group and community work (Ferguson, 2001; Warren-Adamson, 2006). These services must be rendered on a continuous basis, so that the service is considered 
as a resource in the community (Pierson, 2002; Pithouse, Lindsell \& Chueng, 1998, Smith, 1996).

From the above it is evident that social workers at child and family welfare organisations rendering child protection services should focus strongly on utilising existing community resources to prevent the removal of children, but in the absence of such resources, should also focus on the development of appropriate support services (prevention and early intervention) to prevent statutory services in line with current welfare policy.

\section{FAMILY SUPPORT SERVICES}

One of the most important reasons for the development of family support services relates to the high incidence of child abuse and neglect in America in the 1970s, which led to a re-evaluation of the approach to service delivery in child and family welfare services, and a realisation of the importance of family support. Family support services aim to limit the entrance of families into the welfare system and the need for statutory services by rendering preventative services before the onset of a crisis. Community-based services that support and strengthen the family as a unit are emphasized (Chaffin, Bonner \& Hill, 2001; McCroskey, Pecora, Franke, Christie \& Lorthridge, 2012; Weissbound, 1994).

The desired outcome of family support services is the expansion of the family's social networks by linking the family to resources in the community, thereby preventing social isolation. Engagement with these services also leads to an increase in skills, especially parenting skills which help to ensure effective child care. Effective family support thus entails that families have access to a wide range of services in the organisation or community where their parenting skills are developed while their networks are expanded in order to encourage independent functioning (Kagan, 1996; MacDonald, 2005; Manalo \& Meezan, 2000).

The availability of family support services means that pressure on the social worker decreases as at-risk families are involved in programmes offered in the organisation or community. Involvement in these activities is deemed as a crucial part of the preventative and early intervention plan, with non-participation by the parents possibly resulting in removal in the children.

Research (Van den Berg \& Weyers, 2004) into community work services rendered by Non-Governmental Organisations (NGOs) in the North West Province of South Africa, found that only $15 \%$ of the programmes were continuous and that most of the services were largely short term and educational in nature. Community education was emphasized, while a social developmental model was significantly underutilized. From an analysis of the projects mentioned in this research, it seems that continuous community-based support services are seldom available to families. Of a total of 48 projects only four were day care centres and only one afterschool care centre. None of these institutions offered parent guidance or education. 
In conclusion it is evident that community-based family support services available to atrisk families at child and family welfare organisations, should be investigated to determine the types of services available to them.

\section{METHODOLOGY AND RESEARCH DESIGN}

An empirical investigation was undertaken in the Western Cape area and a combination of quantitative and qualitative approaches was used (Fouché \& De Vos, 2011). This research can be classified as exploratory and descriptive research, (Fouché \& De Vos, 2011; Grinnell \& Williams, 1990), as these designs are suitable for qualitative as well as quantitative methods of research (Fouché \& De Vos, 2011).

The population (Grinnell \& Williams, 1990; Strydom, 2011) consisted of all the social workers who delivered family preservation services at NGOs in a specific geographical area. Purposive selection according to the non-probability selection classification (Strydom, 2011; 2002; Grinnell \& Williams, 1990) was used for sampling, as only social workers who had been delivering family prevention services for at least a year, were included. The population consisted of $61(\mathrm{~N}=61)$ social workers.

Quantitative and qualitative data were gathered through the administration of a selfadministered semi-structured questionnaire (Delport \& Roestenburg, 2011). A deductive method was followed as open and closed questions (Rubin \& Babbie, 2007) were developed, based on the literature study. The questionnaire was tested in a pilot study so that the necessary changes could be made before data collection took place (Delport \& Roestenburg, 2011; Rubin \& Babbie, 2007).

The questionnaires were distributed through the managers, to the organisations. Fiftyeight $(\mathrm{n}=58)$ of the $61(\mathrm{~N}=61)$ respondents completed the questionnaire. A response of 95\% was thus obtained from the population.

The quantitative data were processed by computer while the qualitative data were processed by hand. The data provided by the respondents were subsequently discussed in greater detail by a focus group (Greef, 2011). A combination of techniques was thus used (Weyers, Strydom \& Huisamen, 2008).

Purposive selection (Greeff, 2011) was utilised to identify participants for inclusion in the focus group discussions. Two social workers from each of the organisations involved in the investigation were included. This composition was in compliance with the criteria in the literature (Greeff, 2011), which state that five to 10 members are considered suitable to form a focus group. Only one focus group session was held as the information generated during this discussion largely repeated or supported the data already collected from the respondents.

The interview was transcribed and used to support or further inform the data already gathered. The identifying particulars of the respondents and the participants were treated as confidential in accordance with the ethical code of the social work profession. 


\section{RESULTS OF THE STUDY}

The results of the study are explained with reference to the research questions which were mainly designed to determine:

- The nature of the support or preventative services available to at-risk families in the communities and the organisations.

- The regular availability of the services.

- The perceptions of the social workers regarding the rendering of preventative or support services to at-risk families.

\section{Profile of respondents and focus group members}

Most $(28=48.3 \%)$ of the respondents $(n=58)$ were between the ages of 23 and 29. The majority of the respondents had between one and four years' work experience, were in the early adulthood life phase and had been in the service of a family welfare organisation for between one and four years. Family preservation services were thus delivered mostly by young adult workers.

\section{Availability of support services to at-risk families on case-loads}

The respondents were asked to identify which family support or community work services in their organisations or communities are available to at-risk families on their case-load. The results are presented in Table 1.

\section{TABLE 1}

\section{AVAILABILITY OF SUPPORT SERVICES IN ORGANISATIONS AND COMMUNITY}

\begin{tabular}{|c|c|c|c|c|c|c|c|c|}
\hline \multirow{3}{*}{ Support services } & \multicolumn{4}{|c|}{ Availability in organisations } & \multicolumn{4}{|c|}{ Availability in community } \\
\hline & Yes & No & $\begin{array}{c}\text { No } \\
\text { answer }\end{array}$ & $\underset{(\%)}{N}$ & Yes & No & $\begin{array}{c}\text { No } \\
\text { answer }\end{array}$ & $\begin{array}{l}\mathbf{N} \\
(\%)\end{array}$ \\
\hline & $\mathbf{f}(\%)$ & $\mathbf{f}(\%)$ & $\mathbf{f}(\%)$ & & $\mathbf{f}(\%)$ & $\mathbf{f}(\%)$ & $\mathbf{f}(\%)$ & \\
\hline $\begin{array}{l}\text { Programmes for at-risk } \\
\text { families }\end{array}$ & & & & & & & & \\
\hline $\begin{array}{l}\text { Full day pre-school care } \\
\text { for at-risk children }\end{array}$ & $\begin{array}{c}9 \\
(15.5)\end{array}$ & $\begin{array}{c}43 \\
(74.1)\end{array}$ & $\begin{array}{c}6 \\
(10.3)\end{array}$ & $\begin{array}{c}58 \\
(100)\end{array}$ & $\begin{array}{c}31 \\
(53.4)\end{array}$ & $\begin{array}{c}7 \\
(12.1)\end{array}$ & $\begin{array}{c}20 \\
(34.5)\end{array}$ & $\begin{array}{c}58 \\
(100)\end{array}$ \\
\hline $\begin{array}{l}\text { Day care for at-risk } \\
\text { children where abuse and } \\
\text { neglect occurs }\end{array}$ & $\begin{array}{c}8 \\
(13.8)\end{array}$ & $\begin{array}{c}44 \\
(75.9)\end{array}$ & $\begin{array}{c}6 \\
(10.3)\end{array}$ & $\begin{array}{c}58 \\
(100)\end{array}$ & $\begin{array}{c}18 \\
(31.0)\end{array}$ & $\begin{array}{c}9 \\
(15.5)\end{array}$ & $\begin{array}{c}31 \\
(53.4)\end{array}$ & $\begin{array}{c}58 \\
(100)\end{array}$ \\
\hline Play groups & $\begin{array}{c}12 \\
(20.7)\end{array}$ & $\begin{array}{c}43 \\
(74.1)\end{array}$ & $\begin{array}{c}3 \\
(5.2)\end{array}$ & $\begin{array}{c}58 \\
(100)\end{array}$ & $\begin{array}{c}22(37 \\
.9)\end{array}$ & $9(15$. & $\begin{array}{l}27(46 . \\
6)\end{array}$ & $\begin{array}{c}58 \\
(100)\end{array}$ \\
\hline $\begin{array}{l}\text { Parent and baby/toddler } \\
\text { groups }\end{array}$ & $\begin{array}{c}4 \\
(6.9)\end{array}$ & $\begin{array}{c}49 \\
(84.5)\end{array}$ & $\begin{array}{c}5 \\
(8.6)\end{array}$ & $\begin{array}{c}58 \\
(100)\end{array}$ & $\begin{array}{c}17 \\
(29.3)\end{array}$ & $\begin{array}{c}9 \\
(15.5)\end{array}$ & $\begin{array}{c}32 \\
(55.2)\end{array}$ & $\begin{array}{c}58 \\
(100)\end{array}$ \\
\hline $\begin{array}{l}\text { Child care services for } \\
\text { parents who attend } \\
\text { programmes or services }\end{array}$ & $\begin{array}{c}4 \\
(6.9)\end{array}$ & $\begin{array}{c}41 \\
(70.7)\end{array}$ & $\begin{array}{c}13 \\
(22.4)\end{array}$ & $\begin{array}{c}58 \\
(100)\end{array}$ & $\begin{array}{c}13 \\
(22.4)\end{array}$ & $\begin{array}{c}9 \\
(15.5)\end{array}$ & $\begin{array}{c}36 \\
(62.1)\end{array}$ & $\begin{array}{c}58 \\
(100)\end{array}$ \\
\hline $\begin{array}{l}\text { Parent guidance or } \\
\text { education groups for at- } \\
\text { risk parents }\end{array}$ & $\begin{array}{c}40 \\
(69.0)\end{array}$ & $\begin{array}{c}15 \\
(25.9)\end{array}$ & $\begin{array}{c}3 \\
(5.2)\end{array}$ & $\begin{array}{c}58 \\
(100)\end{array}$ & $\begin{array}{c}21 \\
(36.2)\end{array}$ & $\begin{array}{c}5 \\
(8.6)\end{array}$ & $\begin{array}{c}32 \\
(55.2)\end{array}$ & $\begin{array}{c}58 \\
(100)\end{array}$ \\
\hline $\begin{array}{l}\text { Support groups for women } \\
\text { who experience domestic } \\
\text { violence }\end{array}$ & $\begin{array}{c}12 \\
(20.7)\end{array}$ & $\begin{array}{c}36 \\
(62.1) \\
\end{array}$ & $\begin{array}{c}10 \\
(17.2)\end{array}$ & $\begin{array}{c}58 \\
(100)\end{array}$ & $\begin{array}{c}13 \\
(22.4)\end{array}$ & $\begin{array}{l}9 \\
(15.5)\end{array}$ & $\begin{array}{c}36 \\
(62.1) \\
\end{array}$ & $\begin{array}{c}58 \\
(100)\end{array}$ \\
\hline
\end{tabular}




\begin{tabular}{|c|c|c|c|c|c|c|c|c|}
\hline $\begin{array}{l}\text { Life skills programmes for } \\
\text { school children from at- } \\
\text { risk families }\end{array}$ & $\begin{array}{c}45 \\
(77.6)\end{array}$ & $\begin{array}{c}10 \\
(17.2)\end{array}$ & $\begin{array}{c}3 \\
(5.2)\end{array}$ & $\begin{array}{c}58 \\
(100)\end{array}$ & $\begin{array}{c}30 \\
(51.7)\end{array}$ & $\begin{array}{c}3 \\
(5.2)\end{array}$ & $\begin{array}{c}25 \\
(43.1)\end{array}$ & $\begin{array}{c}58 \\
(100)\end{array}$ \\
\hline $\begin{array}{l}\text { Home visits by volunteers } \\
\text { to at-risk families (help } \\
\text { with preservation of } \\
\text { household) }\end{array}$ & $\begin{array}{c}9 \\
(15.5)\end{array}$ & $\begin{array}{c}42 \\
(72.4)\end{array}$ & $\begin{array}{c}7 \\
(12.1)\end{array}$ & $\begin{array}{c}58 \\
(100)\end{array}$ & $\begin{array}{c}11 \\
(19.0)\end{array}$ & $\begin{array}{c}17 \\
(29.3)\end{array}$ & $\begin{array}{c}30 \\
(51.7)\end{array}$ & $\begin{array}{c}58 \\
(100)\end{array}$ \\
\hline $\begin{array}{l}\text { Other } \\
\text { "Eye on the child"- } \\
\text { programme }\end{array}$ & 17.2 & $\begin{array}{c}0 \\
(0)\end{array}$ & $\begin{array}{c}48 \\
(82.8)\end{array}$ & $\begin{array}{c}58 \\
(100) \\
\end{array}$ & $\begin{array}{c}0 \\
(0)\end{array}$ & $\begin{array}{c}0 \\
(0)\end{array}$ & $\begin{array}{c}58 \\
(100) \\
\end{array}$ & $\begin{array}{c}58 \\
(100) \\
\end{array}$ \\
\hline $\begin{array}{l}\text { Programmes for any } \\
\text { family in the community } \\
\text { Programmes like after- } \\
\text { school clubs for school } \\
\text { children }\end{array}$ & $\begin{array}{c}16 \\
(27.6)\end{array}$ & $\begin{array}{c}32 \\
(55.2)\end{array}$ & $\begin{array}{c}10 \\
(17.2)\end{array}$ & $\begin{array}{c}58 \\
(100)\end{array}$ & $\begin{array}{c}1 \\
(1.7)\end{array}$ & $\begin{array}{c}4 \\
(6.9)\end{array}$ & $\begin{array}{c}53 \\
(91.4)\end{array}$ & $\begin{array}{c}58 \\
(100)\end{array}$ \\
\hline Holiday activities & $\begin{array}{c}44 \\
(75.9)\end{array}$ & $\begin{array}{c}12 \\
(20.7)\end{array}$ & $\begin{array}{c}2 \\
(3.4)\end{array}$ & $\begin{array}{c}58 \\
(100)\end{array}$ & $\begin{array}{c}0 \\
(0)\end{array}$ & $\begin{array}{c}1 \\
(1.7)\end{array}$ & $\begin{array}{c}57 \\
(98.3)\end{array}$ & $\begin{array}{c}58 \\
(100)\end{array}$ \\
\hline $\begin{array}{l}\text { Adult education for } \\
\text { community members }\end{array}$ & $\begin{array}{c}13 \\
(22.4)\end{array}$ & $\begin{array}{c}32 \\
(55.2)\end{array}$ & $\begin{array}{c}13 \\
(22.4)\end{array}$ & $\begin{array}{c}58 \\
(100)\end{array}$ & $\begin{array}{c}2 \\
(3.4)\end{array}$ & $\begin{array}{c}0 \\
(0)\end{array}$ & $\begin{array}{c}56 \\
(96.6)\end{array}$ & $\begin{array}{c}58 \\
(100)\end{array}$ \\
\hline $\begin{array}{l}\text { Other } \\
\text { Home care services for } \\
\text { elderly and terminally ill } \\
\text { persons } \\
\text { ABBA (Substance abuse } \\
\text { programme) }\end{array}$ & $\begin{array}{c}1 \\
(1.7) \\
1 \\
(1.7)\end{array}$ & $\begin{array}{c}0 \\
(0) \\
0 \\
(0)\end{array}$ & $\begin{array}{c}57 \\
(98.3) \\
\\
57 \\
(98.3) \\
\end{array}$ & $\begin{array}{c}58 \\
(100) \\
\\
58 \\
(100)\end{array}$ & $\begin{array}{c}0 \\
(0)\end{array}$ & $\begin{array}{c}0 \\
(0)\end{array}$ & $\begin{array}{c}0 \\
(0)\end{array}$ & $\begin{array}{c}0 \\
(0)\end{array}$ \\
\hline
\end{tabular}

$\mathrm{n}=58$

\section{(a) Programmes for at-risk families}

Table 1 shows that life skills programmes for school children of at-risk families are most often rendered (45=77.6\%). This finding confirms Van den Bergh and Weyers' study (2004) who found that most of the community work services rendered by NGOs in the North West Province, were rendered to children and were aimed at increasing life skills. Nel and Roestenburg (2004) found that parents also expressed a need for such programmes for their children.

Parent guidance or education groups is the service rendered second most often. Forty (69.0\%) respondents indicated that this service was available in their organisations. This research finding differs from that of Van den Bergh and Weyers (2004), that the building of parenting skills received only limited attention, while Nel and Roestenburg (2004) found that the development of parenting skills was one of the greatest needs of parents of pre-school children.

Only about a fifth of the respondents indicated that all the other support service were available in their organisations.

Twelve (20.7\%) respondents indicated that support groups for women who experienced domestic violence were available in their organisation, and $13(22.4 \%)$ respondents indicated that it was available in the community. More than half of the respondents thus did not offer support groups for women experiencing domestic violence, although according to research (Hazen, Connelly, Kelleher, Landsverk \& 
Barth, 2004; Horner, 2005; Jones, Gross \& Becker, 2002) domestic violence correlates strongly with the incidence of child abuse and neglect.

Pre-school care and day care services are probably also not available to most of the atrisk families in the communities where the family welfare organisations render services. For example, only a small percentage $(8=13,8 \%)$ indicated that day care was available in the organisation and $18(31.0 \%)$ respondents noted that the service was available in the community. Thirty-one (53.4\%) respondents did not complete this section, which probably means that they were unsure whether the resource existed. The scarcity of these child care services rendered by welfare organisations is also confirmed by other SA research (Van den Berg \& Weyers, 2004).

Although family welfare organisations probably do not have the financial resources to render this type of service, it also seems that the more affordable forms of services, are also lacking, which will be discussed subsequently.

Play groups are not an option for the children of at-risk families in the organisations of most $(43=74.1 \%)$ of the respondents, and almost half $(27=46.6 \%)$ of the respondents could not indicate whether this resource was available in the community. Parent and baby/toddler groups were also not offered by most $(49=89.5 \%)$ organisations although this is an affordable service which could easily be combined with parent education. Nel and Roestenburg (2004) found that parents expressed a need for more knowledge about how to socialise with their pre-school children. This need could be addressed by these two services which are affordable, and considered a general service to be rendered to atrisk families in the UK and in France as attested in literature (Action for children, 2008; Cannan, 1997; Gardner, 2003; Smith, 1996:95).

Regarding child care facilities while parents attend services at the welfare organisations, only four (6.9\%) respondents indicated that such services were available. This type of service should be offered by the organisation itself to make it easier for parents to attend programmes, especially parent education (Daniel \& Rioch, 2007; Keller \& McDade, 2000; Nicholson, Brenner \& Fox, 1999).

Home visiting services are also seldom available. Almost $75 \%(42=72.4 \%)$ of the respondents indicated that the service was not available at their organisations, which means that home visiting services using volunteers to support at-risk families, are not offered as an intervention strategy to enhance family preservation. Home visiting programmes are however considered to be the basis of family support given to at-risk families (Chaffin et al., 2001; Kirkpatrick, Barlow, Stewart-Brown \& Davis, 2007), and are considered an important intervention strategy for the prevention of child abuse and neglect (Daro, 2002; MacDonald, 2005).

\section{Availability of support services in the community}

As to the availability of support services for at-risk families in the community Table 1 shows that most respondents did not complete this section, probably because they were unsure whether the service was available. This means that families would also not be referred to these services even if they did exist. 
It is evident from the above that there is not a wide range of support services available to at-risk families at the organisations included in this investigation. Parent guidance or education services are the service most often rendered and children are generally involved in life skills groups It was also found that services are lacking where at-risk parents can make contact with other families and appropriate resources, and in so doing extend their informal support network, which would accord with the purpose of family support services (Chaffin et al., 2001; Kagan, 1996; Manalo \& Meezan, 2000; McCroskey et al., 2012).

\section{(b) Other programmes or services}

The Isolabantwana: "Eye of the child"-programme is mentioned by a limited number $(10=17.2 \%)$ of respondents as being available to at-risk families. This programme is specifically aimed at child protection (Doran, 1999) and not family support, but does offer support to social workers with regard to their workload.

No other programmes were mentioned by respondents as being available in their organisations, which means that family support programmes similar to these developed countries are not offered, but also that no indigenous programmes had been developed either.

\section{(c) Programmes accessible to any family in the community}

The programme offered to all families in the community, and which is most often run by these organisations, is holiday activities for children (44=75.9\%). After-school clubs $(16=27.6 \%)$ and adult education programmes $(13=22.4 \%)$ are offered by a limited number of organisations. Thus family organisations also do not offer projects open to all families on a regular basis.

\section{(d) Other programmes}

Only two (3.4\%) respondents mentioned other programmes, both of which were developed in co-operation with other institutions. Co-operation between organisations with regard to resources as one of the organisations in this investigation has done, especially in the case of substance abuse, is strongly advocated in literature (McAlpine, Courts Marshall \& Harper Doran, 2001; McCroskey et al., 2012; Semidei, Feig-Radel \& Nolan, 2001).

Apparently no other programmes are offered for all community members and no programmes specifically for men, a finding that concurs with the research of Van den Berg and Weyers (2004).

\section{Do parent guidance and education groups and life skills programmes fulfil the needs of at-risk families?}

The phenomenon that family support services were only rendered to a limited degree, was further investigated. The focus group members were asked whether parent education groups and life skills programmes fulfilled the needs of at-risk families on their case-loads. The sub-themes, categories and the narratives of the participants are presented in Table 2. 


\section{TABLE 2}

PERSPECTIVES ON WHETHER PARENT GUIDANCE AND LIFE SKILLS GROUPS FULFIL THE NEEDS OF AT-RISK FAMILIES

\begin{tabular}{|c|c|c|}
\hline Sub-themes & Categories & Narratives \\
\hline $\begin{array}{l}\text { 1. Parent gui- } \\
\text { dance and } \\
\text { life skills } \\
\text { groups are } \\
\text { not } \\
\text { sufficient }\end{array}$ & 1. Lack of time & $\begin{array}{l}\text { - "Parent guidance and life skills groups are not, } \\
\text { sufficient, but that is all for which there is time." } \\
\text { "'Ouerleiding en lewensvaardigheidsgroepe is nie } \\
\text { voldoende nie, maar dit is al waarvoor daar tyd } \\
\text { is.") } \\
\text { - "No, they are not sufficient" ("Nee, dis nie } \\
\text { voldoende nie.") }\end{array}$ \\
\hline \multirow[t]{2}{*}{$\begin{array}{l}\text { More staff } \\
\text { are } \\
\text { required } \\
\text { for preven- } \\
\text { tative } \\
\text { service } \\
\text { delivery }\end{array}$} & $\begin{array}{l}\text { 1. Separation of case } \\
\text { and community } \\
\text { work services }\end{array}$ & $\begin{array}{l}\text { - I should say that there should be a system where } \\
\text { there are social workers like us that only do } \\
\text { statuatory work, and another section of social } \\
\text { work that only does preventative work so that } \\
\text { parent guidance could be done and preventative } \\
\text { work for drink and drugs." ("Ek sal sê kry 'n } \\
\text { sisteem waar daar maatskaplike werkers is soos } \\
\text { ons wat net die statutêre werk doen, en 'n ander } \\
\text { afdelingvan maatskaplike werk wat net } \\
\text { voorkomende werk doen, maar dat jy dit kry dat } \\
\text { daar ouerskapsvaardighede gedoen word, en } \\
\text { byvoorbeeld voorkomende werk vir drank en } \\
\text { dwelms.") } \\
\text { "If you only do the therapeutic work and } \\
\text { somebody else does the community work."("As jy } \\
\text { net die terapeutiese werk doen en iemand anders } \\
\text { doen die gemeenskapswerk.") } \\
\text { "If you can manage the auxillary social workers } \\
\text { so that they can do this work (meaning the } \\
\text { community work), so that you as social worker } \\
\text { are the manager or if you can only do the } \\
\text { children's court investigations." ("As jy } \\
\text { maatskaplike hulpwerkers kan bestuur dat hulle } \\
\text { hierdie tipe werk (menende gemeenskapswerk) } \\
\text { kan doen, dat jy as maatskaplike werker dan nou } \\
\text { of die bestuurder is of as jy nou net } \\
\text { kinderhofondersoeke doen.") }\end{array}$ \\
\hline & $\begin{array}{l}\text { 2. Irreconcilability of } \\
\text { roles of case worker } \\
\text { and community } \\
\text { worker }\end{array}$ & $\begin{array}{l}\text { - "For me it is about the different roles that the } \\
\text { social worker must play with regards to case } \\
\text { work and community work and theyare } \\
\text { irreconcilable as they see you as the woman that } \\
\text { removes their kids. If you start a project, they are } \\
\text { not interested, they are afraid you will notice } \\
\text { something in that project, that then puts them on } \\
\text { the spot." ("Dit gaan vir my oor die verskillende } \\
\text { rolle wat die maatskaplike werker moet vertolk in } \\
\text { terme van gevalle- en gemeenskapswerk, en hulle } \\
\text { is nie versoenbaar nie, want hulle sien vir jou as } \\
\text { die vrou wat die kinders verwyder. As jy'n projek } \\
\text { aanbied, hulle stel nie belang nie, hulle is bang jy } \\
\text { sien iets raak in daai projek wat nou weer vir } \\
\text { hulle op die spot sit.") }\end{array}$ \\
\hline
\end{tabular}




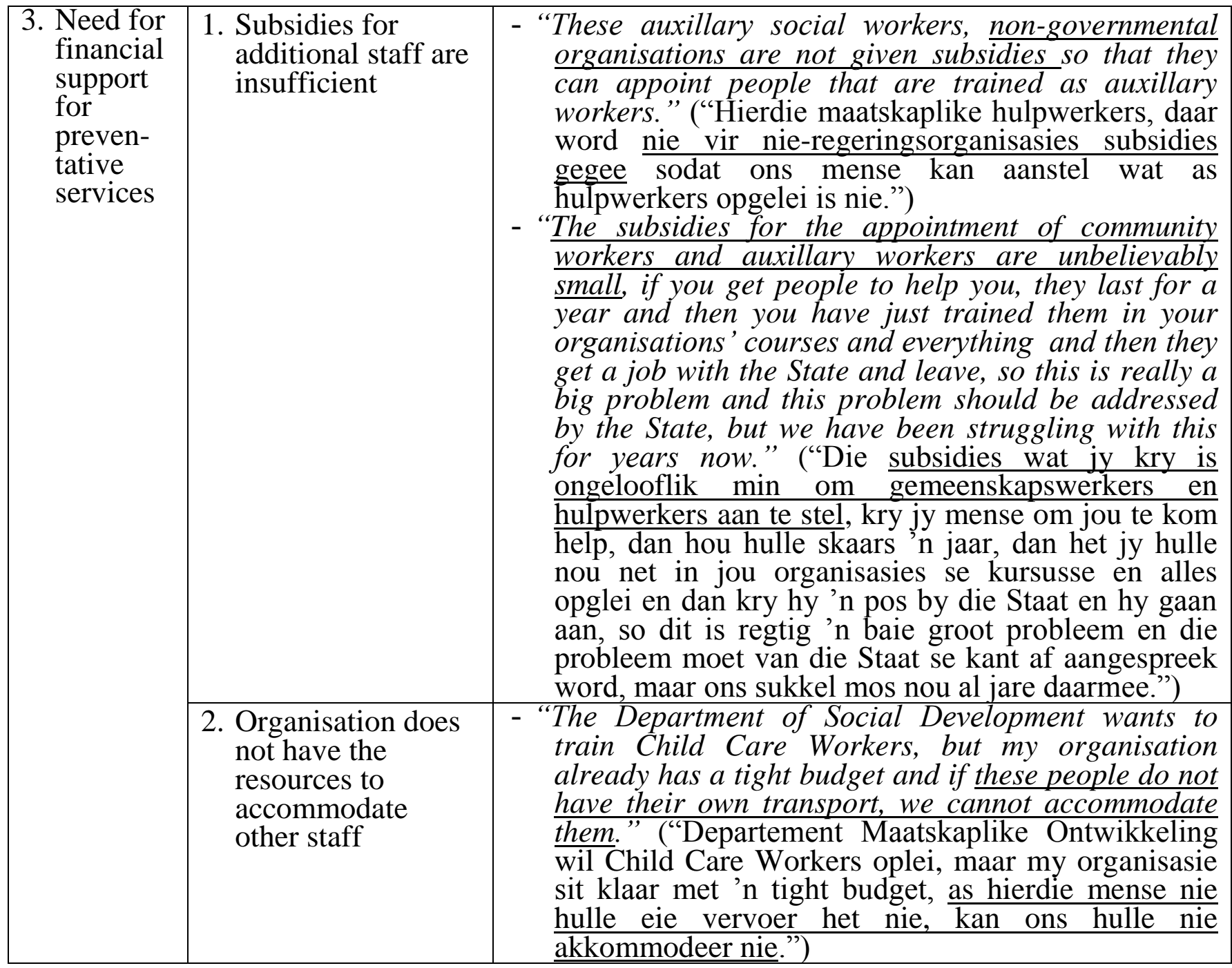

\section{(a) Parent guidance and life skills programmes are insufficient}

It would appear from the responses of the participants as indicated in Table 2, that parent guidance and life skills programmes for children are insufficient to meet the needs of atrisk families. The only category that emerged in this sub-theme, is that there is not enough time to render other preventative services, which can also be associated with a shortage of people power. The shortage of social workers to render services is confirmed in both South African literature (Lombard \& Kleijn, 2006; September, 2007) and research (Brown \& Neku, 2005; Strydom, 2010).

\section{(b) More staff are needed for the rendering of support services}

The second sub-theme is that additional staff is needed to render support services. The main category to emerge holds that the delivery of case work and community work should be separated so that different staff members are used to render the therapeutic and the support services, respectively. Another category that emerged which is an extension of the former, is the view that the roles executed in the different methods are irreconcilable and that this affects the delivery of preventative services. 


\section{(c) Financial support is needed for the delivery of support services}

The focus of the final sub-theme is on the financial support that organisations need to appoint other staff members (e.g auxiliary workers) to render support services. The categories identified by the participants, centred on insufficient subsidies towards appointing more staff, resulting in preventative services not being rendered. The lack of funds in family welfare organisations in SA, which affects service rendering, was also confirmed in other studies (Streak \& Poggenpoel, 2005; Weyers \& Van den Berg, 2006).

Another category that emerged is that resources such as transport are not available in the organisation and that it is therefore not possible to appoint more staff members as they could place additional pressure on the already limited resources. Insufficient resources such as vehicles were also identified in the study by Brown and Neku (2005) as a factor hampering service delivery.

In conclusion it is obvious moreover that the participants did not focus on other services which could possibly be needed by at-risk families. They rather concentrated on the reasons for limited preventative/support services which were primarily because financial resources were lacking.

\section{Regularity of service delivery}

The respondents were asked to indicate how regularly the support services were rendered. The results are presented in Table 3.

TABLE 3

REGULARITY OF SUPPORT SERVICES

\begin{tabular}{|c|c|c|c|c|c|c|c|c|c|c|}
\hline \multirow{4}{*}{$\begin{array}{l}\text { SUPPORT } \\
\text { SERVICES }\end{array}$} & \multirow{4}{*}{$\begin{array}{l}\text { Available } \\
\text { in } \\
\text { organisa- } \\
\text { tions }\end{array}$} & \multicolumn{9}{|c|}{ REGULARITY OF SERVICES } \\
\hline & & \multicolumn{3}{|c|}{ Continuous } & \multicolumn{6}{|c|}{$\begin{array}{r}\text { Once off } \\
\end{array}$} \\
\hline & & Daily & $\begin{array}{l}\text { Week- } \\
\text { ly }\end{array}$ & $\begin{array}{c}\text { Month } \\
\text {-ly }\end{array}$ & $\begin{array}{l}\text { Quar- } \\
\text { terly }\end{array}$ & $\begin{array}{l}2 \mathrm{x} \\
\mathrm{yr}\end{array}$ & $\begin{array}{l}\mathbf{1 x} \\
\mathbf{y r}\end{array}$ & $\begin{array}{l}\text { Holi- } \\
\text { days }\end{array}$ & $\begin{array}{l}\text { On } \\
\text { re- } \\
\text { quest }\end{array}$ & $\begin{array}{l}\text { Regulari- } \\
\text { ty not } \\
\text { indicated }\end{array}$ \\
\hline & & $\underset{(\%)}{\mathbf{f}}$ & $\underset{(\%)}{\mathbf{f}}$ & $\begin{array}{l}\mathbf{f} \\
(\%)\end{array}$ & $\begin{array}{c}\mathbf{f} \\
(\%)\end{array}$ & $\begin{array}{c}\mathbf{f} \\
(\%)\end{array}$ & $\begin{array}{c}\mathbf{f} \\
(\%)\end{array}$ & $\underset{(\%)}{\mathbf{f}}$ & $\begin{array}{c}f \\
(\%)\end{array}$ & $\underset{(\%)}{\mathbf{f}}$ \\
\hline $\begin{array}{l}\text { Programmes } \\
\text { for at-risk } \\
\text { families } \\
\text { Full-day pre- } \\
\text { school care for } \\
\text { at-risk } \\
\text { children. }\end{array}$ & $\begin{array}{c}9 \\
(15.5) \\
\end{array}$ & $\begin{array}{c}6 \\
(10.3) \\
\end{array}$ & $\begin{array}{c}2 \\
(3.4)\end{array}$ & $\begin{array}{c}0 \\
(0) \\
\end{array}$ & $\begin{array}{c}0 \\
(0) \\
\end{array}$ & $\begin{array}{c}0 \\
(0) \\
\end{array}$ & $\begin{array}{c}0 \\
(0) \\
\end{array}$ & $\begin{array}{c}0 \\
(0)\end{array}$ & $\begin{array}{c}0 \\
(0) \\
\end{array}$ & $\begin{array}{c}1 \\
(1.7)\end{array}$ \\
\hline $\begin{array}{l}\text { Day care for at- } \\
\text { risk children } \\
\text { where abuse } \\
\text { and neglect } \\
\text { occurs }\end{array}$ & $\begin{array}{c}8 \\
(13.8)\end{array}$ & $\begin{array}{c}4 \\
(6.9)\end{array}$ & $\begin{array}{c}0 \\
(0)\end{array}$ & $\begin{array}{c}0 \\
(0)\end{array}$ & $\begin{array}{c}0 \\
(0)\end{array}$ & $\begin{array}{c}0 \\
(0)\end{array}$ & $\begin{array}{c}0 \\
(0)\end{array}$ & $\begin{array}{c}0 \\
(0)\end{array}$ & $\begin{array}{c}0 \\
(0)\end{array}$ & $\begin{array}{c}4 \\
(6.9)\end{array}$ \\
\hline Play groups & $\begin{array}{c}12 \\
(20.6)\end{array}$ & $\begin{array}{c}5 \\
(8.6)\end{array}$ & $\begin{array}{c}4 \\
(6.9)\end{array}$ & $\begin{array}{c}0 \\
(0)\end{array}$ & $\begin{array}{c}0 \\
(0)\end{array}$ & $\begin{array}{c}0 \\
(0)\end{array}$ & $\begin{array}{c}0 \\
(0)\end{array}$ & $\begin{array}{c}0 \\
(0)\end{array}$ & $\begin{array}{c}0 \\
(0)\end{array}$ & $\begin{array}{c}3 \\
(5.2)\end{array}$ \\
\hline $\begin{array}{l}\text { Parent and } \\
\text { baby/toddler } \\
\text { groups }\end{array}$ & $\begin{array}{c}4 \\
(6.9) \\
\end{array}$ & $\begin{array}{c}1 \\
(1.7) \\
\end{array}$ & $\begin{array}{c}0 \\
(0)\end{array}$ & $\begin{array}{c}1 \\
(1.7)\end{array}$ & $\begin{array}{c}0 \\
(0) \\
\end{array}$ & $\begin{array}{c}0 \\
(0) \\
\end{array}$ & $\begin{array}{c}0 \\
(0)\end{array}$ & $\begin{array}{c}0 \\
(0)\end{array}$ & $\begin{array}{c}0 \\
(0)\end{array}$ & $\begin{array}{c}2 \\
(3.4) \\
\end{array}$ \\
\hline
\end{tabular}




\begin{tabular}{|c|c|c|c|c|c|c|c|c|c|c|}
\hline $\begin{array}{l}\text { Child care ser- } \\
\text { vices for chil- } \\
\text { dren of parents } \\
\text { attending } \\
\text { programmes }\end{array}$ & $\begin{array}{c}4 \\
(6.9)\end{array}$ & $\begin{array}{c}0 \\
(0)\end{array}$ & $\begin{array}{c}1 \\
(1.7)\end{array}$ & $\begin{array}{c}1 \\
(1.7)\end{array}$ & $\begin{array}{c}0 \\
(0)\end{array}$ & $\begin{array}{c}0 \\
(0)\end{array}$ & $\begin{array}{c}0 \\
(0)\end{array}$ & $\begin{array}{c}0 \\
(0)\end{array}$ & $\begin{array}{c}0 \\
(0)\end{array}$ & $\begin{array}{c}2 \\
(3.4)\end{array}$ \\
\hline $\begin{array}{l}\text { Parent guidance } \\
\text { or education } \\
\text { groups for at- } \\
\text { risk parents }\end{array}$ & $\begin{array}{c}40 \\
(69.0)\end{array}$ & $\begin{array}{c}0 \\
(0)\end{array}$ & $\begin{array}{c}11 \\
(19.0)\end{array}$ & $\begin{array}{c}5 \\
(8.6)\end{array}$ & $\begin{array}{c}7 \\
(12.1)\end{array}$ & $\begin{array}{c}6 \\
(10.3) \\
\end{array}$ & $\begin{array}{c}0 \\
(0)\end{array}$ & $\begin{array}{c}0 \\
(0)\end{array}$ & $\begin{array}{c}0 \\
(0)\end{array}$ & $\begin{array}{c}11 \\
(19.0)\end{array}$ \\
\hline $\begin{array}{l}\text { Support groups } \\
\text { for women ex- } \\
\text { periencing do- } \\
\text { mestic violence }\end{array}$ & $\begin{array}{c}12 \\
(20.7)\end{array}$ & $\begin{array}{c}1 \\
(1.7)\end{array}$ & $\begin{array}{c}4 \\
(6.9)\end{array}$ & $\begin{array}{c}2 \\
(3.4)\end{array}$ & $\begin{array}{c}0 \\
(0)\end{array}$ & $\begin{array}{c}0 \\
(0)\end{array}$ & $\begin{array}{c}1 \\
(1.7)\end{array}$ & $\begin{array}{c}0 \\
(0)\end{array}$ & $\begin{array}{c}0 \\
(0)\end{array}$ & $\begin{array}{c}4 \\
(6.8)\end{array}$ \\
\hline $\begin{array}{l}\text { Life skills pro- } \\
\text { grammes for } \\
\text { school children } \\
\text { from at-risk } \\
\text { families e }\end{array}$ & $\begin{array}{c}45 \\
(77.6)\end{array}$ & $\begin{array}{c}2 \\
(3.4)\end{array}$ & $\begin{array}{c}13 \\
(22.4)\end{array}$ & $\begin{array}{c}1 \\
(1.7)\end{array}$ & $\begin{array}{c}7 \\
(12.1)\end{array}$ & $\begin{array}{c}0 \\
(0)\end{array}$ & $\begin{array}{c}0 \\
(0)\end{array}$ & $\begin{array}{c}2 \\
(3.4)\end{array}$ & $\begin{array}{c}0 \\
(0)\end{array}$ & $\begin{array}{c}20 \\
(34.5)\end{array}$ \\
\hline $\begin{array}{l}\text { Home visits to } \\
\text { at-risk families } \\
\text { by volunteers } \\
\text { (help with the } \\
\text { preservation of } \\
\text { household) }\end{array}$ & $\begin{array}{c}9 \\
(15.5) \\
\end{array}$ & $\begin{array}{c}0 \\
(0)\end{array}$ & $\begin{array}{c}4 \\
(6.9) \\
\end{array}$ & $\begin{array}{c}0 \\
(0) \\
\end{array}$ & $\begin{array}{c}0 \\
(0)\end{array}$ & $\begin{array}{c}0 \\
(0)\end{array}$ & $\begin{array}{c}0 \\
(0)\end{array}$ & $\begin{array}{c}0 \\
(0)\end{array}$ & $\begin{array}{c}1 \\
(1.7) \\
\end{array}$ & $\begin{array}{c}4 \\
(6.8) \\
\end{array}$ \\
\hline $\begin{array}{l}\text { Other: } \\
\text { Eye on the child } \\
\text { programme }\end{array}$ & $\begin{array}{c}10 \\
(17.2)\end{array}$ & $\begin{array}{c}0 \\
(0)\end{array}$ & $\begin{array}{c}0 \\
(0)\end{array}$ & $\begin{array}{c}0 \\
(0)\end{array}$ & $\begin{array}{c}0 \\
(0)\end{array}$ & $\begin{array}{c}0 \\
(0)\end{array}$ & $\begin{array}{c}0 \\
(0)\end{array}$ & $\begin{array}{c}0 \\
(0)\end{array}$ & $\begin{array}{c}0 \\
(0)\end{array}$ & $\begin{array}{c}1 \\
(1.7)\end{array}$ \\
\hline $\begin{array}{l}\text { Programmes } \\
\text { for any family } \\
\text { in the } \\
\text { community } \\
\text { Programmes for } \\
\text { school children } \\
\text { like after-school } \\
\text { clubs }\end{array}$ & $\begin{array}{c}16 \\
(27.6)\end{array}$ & $\begin{array}{c}4 \\
(6.9)\end{array}$ & $\begin{array}{c}6 \\
(10.3)\end{array}$ & $\begin{array}{c}1 \\
(1.7)\end{array}$ & $\begin{array}{c}0 \\
(0)\end{array}$ & $\begin{array}{c}0 \\
(0)\end{array}$ & $\begin{array}{c}0 \\
(0)\end{array}$ & $\begin{array}{c}0 \\
(0)\end{array}$ & $\begin{array}{c}0 \\
(0)\end{array}$ & $\begin{array}{c}5 \\
(8.6)\end{array}$ \\
\hline Holiday clubs & $\begin{array}{c}44 \\
(75.9)\end{array}$ & $\begin{array}{c}0 \\
(0)\end{array}$ & $\begin{array}{c}1 \\
(1.7)\end{array}$ & $\begin{array}{c}0 \\
(0)\end{array}$ & $\begin{array}{c}7 \\
(12)\end{array}$ & $\begin{array}{c}5 \\
(8.6)\end{array}$ & $\begin{array}{c}1 \\
(1.7)\end{array}$ & $\begin{array}{c}18 \\
(31)\end{array}$ & $\begin{array}{c}0 \\
0 \\
(0)\end{array}$ & $\begin{array}{c}12 \\
(20.7)\end{array}$ \\
\hline $\begin{array}{l}\text { Adult educa- } \\
\text { tion for all } \\
\text { members of the } \\
\text { community }\end{array}$ & $\begin{array}{c}13 \\
(22.4)\end{array}$ & $\begin{array}{c}0 \\
(0)\end{array}$ & $\begin{array}{c}2 \\
(3.4)\end{array}$ & $\begin{array}{c}0 \\
(0)\end{array}$ & $\begin{array}{c}2 \\
(3.4)\end{array}$ & $\begin{array}{c}0 \\
(0)\end{array}$ & $\begin{array}{c}1 \\
(1.7)\end{array}$ & $\begin{array}{c}0 \\
(0)\end{array}$ & $\begin{array}{c}0 \\
(0)\end{array}$ & $\begin{array}{c}8 \\
(13.8)\end{array}$ \\
\hline $\begin{array}{l}\text { Other: } \\
\text { Home care ser- } \\
\text { vices for the el- } \\
\text { derly and termi- } \\
\text { nally ill } \\
\text { ABBA } \\
\text { (substance } \\
\text { abuse } \\
\text { programme ) }\end{array}$ & $\begin{array}{c}2 \\
(3.4)\end{array}$ & $\begin{array}{c}0 \\
(0)\end{array}$ & $\begin{array}{c}0 \\
(0)\end{array}$ & $\begin{array}{c}0 \\
(0)\end{array}$ & $\begin{array}{c}0 \\
(0)\end{array}$ & $\begin{array}{c}0 \\
(0)\end{array}$ & $\begin{array}{c}0 \\
(0)\end{array}$ & $\begin{array}{c}0 \\
(0)\end{array}$ & $\begin{array}{c}0 \\
(0)\end{array}$ & $\begin{array}{c}2 \\
(3.4)\end{array}$ \\
\hline
\end{tabular}

(a) Regularity of programmes for at-risk families

According to Table 3 life skills programmes for school children from at-risk families are presented regularly because $13(22.4 \%)$ of the respondents indicated that they were 
available on a weekly basis. Nine $(15.5 \%)$ respondents indicated that these services were offered only quarterly $(7=12 \%)$ or during the holidays.

Parent guidance or education programmes are also not presented regularly. Eleven (19.0\%) respondents indicated that their institutions rendered this service weekly $(11=19.0 \%)$ or monthly $(5=8.6 \%)$. Seven $(7=12.1 \%)$ rendered this service quarterly and the organisations of six $(10.3 \%)$ respondents only rendered this service twice a year.

The above-mentioned services to at-risk families are rendered by a minority of the organisations on a regular basis, which partly confirms the research finding of Weyers and Van den Berg (2004) that most of the community work projects at welfare organisations are short term or once off in nature.

Play groups, and day care for pre-school children are regularly presented, but by a very limited number of organisations. With regard to home visiting services, four $(6.9 \%)$ of the respondents indicated that the services were rendered weekly and one $(1.7 \%)$ that it was rendered upon request.

A number of respondents did not complete the sections about the regularity of the services. The reason for this is not clear; they are probably unsure about how often the services are available which could mean that they do not involve the families on their case-load in these services on a regular basis.

Clearly continuous family support- and preventative services for at-risk families are available only on a limited basis. Services based in the community and which offer support to families on a continuous basis, as suggested in the literature in order to prevent the removal of children (McCroskey et al., 2012, MacDonald, 2005; Pierson, 2002; Weissbound \& Kagan, 1989) are thus not available at the organisations involved in this investigation.

\section{(b) Regularity of programmes offered to any family in the community}

Table 3 shows clearly that the two regular services that are available to any family and are rendered by an extremely limited number of organisations, are after-school clubs and holiday activities for young people. The organisations of the majority of the respondents present the after-school clubs daily $(4=6.9 \%)$, weekly $(6=10.3 \%)$ or monthly $(1=1.7 \%)$. Adult education is also not offered continuously by the few organisations $(13=22.4 \%)$ that do present it.

These services are considered as open-access services (Pithouse et al., 1998; Smith, 1996), as they are rendered to at-risk families as well as to other members of the community. Thus family welfare organisations involved in this study, do not render open-access services on a continuous basis.

\section{DISCUSSION}

In this article the focus was on family preservation and specifically on family support or preventative services available at welfare organisations or in communities to at-risk families, to prevent the removal of children. The nature of the support services rendered 
by most of the organisations, pertains to life skills programmes for school children and parent education groups.

Both services, according to the perceptions of the respondents, are not sufficient to meet the needs of at-risk families, but the initiation of other preventative services is hampered by a shortage of staff as well as the fact that it is expected of the same social worker to render case as well as community work services. The shortage of finances also means other staff cannot be appointed and that resources like vehicles are in limited supply.

Other family support services such as pre-school care, play groups, baby and toddler groups and home visiting programmes are offered to a very limited extent, while no programmes seem to be available exclusively for men. Most of the programmes are not offered on a regular basis which means that at-risk families do not have uninterrupted access to support services.

There also seems to be uncertainty about which resources for at-risk families exist in communities, as most of the respondents could not indicate whether these resources were available there. This means that if these resources were indeed available, families were not referred to them. Social workers thus seem ignorant of the importance of these types of family support programmes. They also seem to be unaware of what type of programme should be considered as family support or prevention services and early intervention services, to promote family preservation.

The result could be that at-risk families are seldom directed to resources that can offer support on a continuous basis, and an important opportunity to expand the families' support networks and to prevent them entering the child welfare system, is thus lost.

This situation should be addressed as the development of for example affordable childcare facilities like play groups for pre-school children offer women the opportunity to spend some time away from their children, as well as giving pre-school children in low income communities access to educational activities. Available child care facilities also make it possible for social workers to involve at-risk parents to whom case work services are rendered, in other education programmes.

Preventative services and programmes should specifically focus on involving men, not only to improve parenting, but also to promote gender equality, as the care of children is not a women's issue only.

Home visiting programmes are particularly applicable because valuable concrete services can be rendered to the family and their capacity to cope can be strengthened. Work loads of social workers are lightened and the capacity of the community can be expanded in accordance with a developmental policy, as volunteers are used. The social networks of families are also developed and social isolation is lessened.

\section{CONCLUSION}

Family preservation is emphasised in SA policy documents, and social work services should be directed towards preventative- and early intervention services to prevent the removal of children. Insufficient family support services are partly due to structural 
obstacles like financial shortages in organisations, but ignorance of the types of services considered as preventative services to implement a developmental perspective and to promote family preservation, also exists. Universities and welfare organisations should pay attention in their curricula and in-service training respectively, inter alia to the different types of support services that should be rendered to promote family preservation. Failing this, at-risk families will not be given the opportunity to overcome their stressors and children will be removed because of the lack of community-based support services.

\section{ACKNOWLEDGEMENT}

This article were made possible by the support of a Marie Curie Action: International Research Staff Exchange Scheme (contract no. 295203: EU FP7-PEOPLE-IRSES, NL_SOCIAL) and co-funding by the South African Department of Science and Technology (DST/CON 0121/2012).

\section{REFERENCES}

ACTION FOR CHILDREN. 2008. Action for children children's centres - helping children and families in most need. September 2008, 1-7.

AL, C.M.W., STAMS, G.J.J.M., BEK, M.S., DAMEN, E.M., ASSCHER, J.J. \& VAN DER LAAN, P.H. 2012. A meta-analysis of intensive family preservation programs: Placement prevention and improvement of family functioning, Children and Youth Services Review, doi:10.1016/childyouth.2012.04.002.

ARMSTRONG, C. \& HILL, M. 2001. Support services for vulnerable families with young children. Child and Family Social Work, 6(4):351-358.

BROWN, M. \& NEKU, R.J. 2005. A historical review of the South African social welfare system and social work practitioners' views on its current status. International Social Work, 48(3):301-312.

CANNAN, C. 1997. Social development with children and families in France. In: CANNAN, C. \& WARREN, C. (eds) Social action with children and families: a community development approach to children and families. London: Routledge, 85102.

CHAFFIN, M., BONNER, B.L. \& HILL, R.F. 2001. Family preservation and family support programs: Child maltreatment outcomes across client risk levels and program types. Child Abuse and Neglect, 25(10):1269-1289.

DANIEL, B. \& RIOCH, C. 2007. In: WILSON, K. \& JAMES, A. (eds) The child protection handbook: the practitioner's guide to safeguarding children. China: Elsevier, 433-450.

DARO, D. 2002. Educating and changing parents: strengthening the primary safety net for children. In: BROWNE, K.D., HANKS, H., STRATTON, P. \& HAMILTON, C. (eds) Early prediction and prevention of child abuse: a handbook. Chichester: John Wiley \& Sons, Ltd. 
DELPORT, C.S.L. \& ROESTENBURG, W.J.H. 2011. Quantitative data collection methods: questionnaires, checklists, structured observation and structured interview schedules. In: DE VOS, A.S., STRYDOM, H., FOUCHÉ, C.B. \& DELPORT, C.S.L. Research at grass roots for the social sciences and human service professions $\left(4^{\text {th }}\right.$ ed). Pretoria: Van Schaik Publishers, 89-99.

DEPARTMENT OF SOCIAL DEVELOPMENT. 2004. Draft Service Delivery Model for Developmental Social Services. Pretoria.

DEPARTMENT OF SOCIAL DEVELOPMENT. 2006. Integrated Service Delivery Model towards Improved Social Services. Pretoria.

DORAN, L. 1999. Eye of the child. Isolabantwana: a community-based child protection programme. Social Work/Maatskaplike Werk, 35(4):396-399.

FERGUSON, H. 2001. Promoting child protection, welfare and healing: the case for developing best practice. Child and Family Social Work, 6(1):1-12.

FOUCHÉ, C.B. \& DE VOS, A.S. 2011. Formal formulations. In: DE VOS, A.S., STRYDOM, H., FOUCHÉ, C.B. \& DELPORT, C.S.L. Research at grass roots for the social sciences and human service professions $\left(4^{\text {th }}\right.$ ed). Pretoria: Van Schaik Publishers, 89-99.

GARDNER, R. 2003. Supporting families: child protection in the community. London: John Wiley \& Sons, Ltd.

GREEFF, M. 2011. Information collection: interviewing. In: DE VOS, A.S., STRYDOM, H., FOUCHÉ, C.B. \& DELPORT, C.S.L. Research at grass roots for the social sciences and human service professions $\left(4^{\text {th }} \mathrm{ed}\right)$. Pretoria: Van Schaik Publishers, 89-99.

GRINNELL, R.M. \& WILLIAMS, M. 1990. Research in social work: a primer. Itasca, Ill.: F.E. Peacock.

HAZEN, A.L., CONNELLY, C.D., KELLEHER, K., LANDSVERK, J. \& BARTH, R. 2004. Intimate partner violence among female caregivers of children reported for child maltreatment. Child Abuse and Neglect, 28(3):301-319.

HORNER, G. 2005. Domestic violence and children. Journal of Pediatric Health Care. doi:10.1016/j.pedhc.2005.02.002.

JONES, P.L., GROSS, E. \& BECKER, I. 2002. The characteristics of domestic violence victims in a child protective service load. Families in Society: The Journal of Contemporary Human Services, 83(4):405-415.

KAGAN, S.L. 1996. America's family support movement: a moment of change. In: ZIGLER, E.F., KAGAN, S.L. \& HALL, N.W. (eds) Children, families and government: Preparing for the twenty first century. Cambridge: Cambridge University Press, 156-170. 
KATZ, I., LA PLACA, V. \& HUNTER, S. 2007. Barriers to inclusion and succesfull engagement of parents in mainstream services. Policy Research Bureau, Joseph Rowntree Foundation, York, England. [Online] Available: (www.jrf.org.uk/bookshop/).

KELLER, J. \& McDADE, K. 2000. Attitudes of low-income parents toward seeking help with parenting: Implications for practice. Child Welfare, LXXXIX(3):285-312.

KIRKPATRICK, S., BARLOW, J., STEWART-BROWN, S. \& DAVIS, H. 2007. Working in partnership: user perceptions of intensive home-visiting. Child Abuse Review, 16(1):32-46.

LOMBARD, A. \& KLEIJN, W.C. 2006. Statutory social services: an integral part of developmental social welfare service delivery. Social Work/MaatskaplikeWerk, 42(3/4):213-233.

LORD, P., SOUTHCOTT, C.E. \& SHARP, C. 2011. Targeting children's centre services on the most needy families. LGA Research Report, Slough:NFER.

MacDONALD, G. 2005. Intervening with Neglect. In: TAYLOR, J. \& DANIEL, B. (eds) Child neglect: practice issues for health and social care. London: Jessica Kingsley Publishers, 279-290.

MANALO, V. \& MEEZAN, W. 2000. Toward building a typology for the evaluation of services in family support programs. Child Welfare, LXXIX(4):405-429.

McALPINE, C., COURTS MARSHALL, C. \& HARPER DORAN, N. 2001. Combining child welfare and substance abuse services: a blended model of intervention. Child Welfare, LXXX(2):129-220.

McCROSKEY, J., PECORA, P., FRANKE, T., CHRISTIE, C. \& LORTHRIDGE, J. 2012. Can public child welfare help to prevent child maltreatment? Promising findings from Los Angeles. Journal of Family Strenghts, 12(1). [Online] Available: http//digitalcommons.library.tmc.edu/jfs/vol12/1221/5.

MINISTRY FOR WELFARE AND POPULATION DEVELOPMENT. 1997. White Paper for Social Welfare. Government Gazette, 386 (18166). Pretoria, 8 August.

NEL, H. \& ROESTENBURG, W. 2004. Assessment of a community: promoting an equitable society through inclusion and empowerment. Social Work/Maatskaplike Werk, 40(2):113-123.

NICHOLSON, B.C., BRENNER, V. \& FOX, R.A. 1999. A community-based parenting programme with low-income mothers of young children. Families in Society: The Journal of Contemporary Human Services, 80(3):247-253.

PECORA, J., FRASER, M.W., NELSON, K.E., McCROSKEY, J. \& MEEZAN, W. 1995. Evaluating family based services. New York: Hawthorne.

PIERSON, J. 2002. Tackling social exclusion. London: Routledge.

PITHOUSE, A., LINDSELL, S. \& CHUENG, M. 1998. Family support and family centre services. Aldershot: Ashgate. 
REPUBLIC OF SOUTH AFRICA. 2005. Children's Act: No 38 of 2005 Government Gazette, 492 (28944). Pretoria: Government Printers.

REPUBLIC OF SOUTH AFRICA. 2007. Children's Act: No 41 of 2007 Government Gazette, 513 (30884). Pretoria: Government Printers.

RUBIN, A. \& BABBIE, E. 2007. Essential research methods for social work. California: Thomson Brooks/Cole.

RYAN, J.P. \& SCHUERMAN, J.R. 2004. Matching families with specific family preservation services: a study of service effectiveness. Children and Youth Services Review, 26(4):347-472.

SEMIDEI, J., FEIG-RADEL, L. \& NOLAN, C. 2001. Substance abuse and child welfare: clear linkages and promising responses. Child Welfare, LXXX(2):109-128.

SEPTEMBER, R.L. 2007. Separating social welfare services and social welfare grants: challenges and opportunities. Social Work/Maatskaplike Werk, 43(2):93-105.

SMITH, T. 1996. Family centers \& bringing up young children. London: HMSO.

STREAK, J. \& POGGENPOEL, S. 2005. Towards social welfare services for all vulnerable children in South Africa: a review of policy development, budgeting and service delivery. Children's Budget Unit, Budget Information Service, Idasa. 31 March 2005.

STRYDOM, H. 2011. Sampling in the quantitative paradigm. In: DE VOS, A.S., STRYDOM, H., FOUCHÉ C.B. \& DELPORT, C.S.L. Research at grass roots: for the social sciences and human service professions $\left(4^{\text {th }}\right.$ ed). Pretoria: Van Schaik Publishers, 222-234.

STRYDOM, M. 2010. The implementation of family preservation services: perspectives of social workers at NGOs. Social Work/Maatskaplike Werk, 46(2):192-208.

TRACY, E.M. 1995. Family preservation and home-based services. Encyclopaedia of Social Work $\left(19^{\text {th }}\right.$ ed). Washington: NASW Press, 973-981.

VAN DEN BERG, A.M. \& WEYERS, M.L. 2004. Die gemeenskaplswerkdienste van die private welsynsektor: 'n Profiel met implikasies. Social Work/Maatskaplike Werk, 40(4):344-365.

WARREN-ADAMSON, C. 2006. Research review. Family centres: a review of the literature. Child and Family Social Work, 11(2):171-182.

WEYERS, M., STRYDOM, H. \& HUISAMEN, A. 2008. Triangulation in social work research: the theory and examples of its practical application. Social Work/MaatskaplikeWerk, 44(2):207-222.

WEYERS, M.L. \& VAN DEN BERG, A.M. 2006. The success factors in community work services: A critical incident study. International Social Work, 49(2):177-187. 
WEISSBOUND, B. 1994. The evolution of the family resource movement. In: KAGAN, S. \& WEISSBOUND, B. (eds) Putting families first: America's family support movement and the challenge of change. San-Francisco: Jossey-Bass, Inc., 2847.

WEISSBOUND, B. \& KAGAN, S.L. 1989. Family support programs: catalyst for change. American Journal of Ortopsychiatry, 59(1):20-31.

Dr Marianne Strydom, Department of Social Work, Stellenbosch University, Stellenbosch, South Africa. 